Przegląd Prawa Konstytucyjnego

--ISSN 2082-1212---------

DOI 10.15804/ppk.2017.05.17

-Nr 5 (39)/2017--------

\title{
Sprawozdanie
}

\section{Seminarium Badaczy Prawa Konstytucyjnego Instytucje i rozwiązania prawne państw obcych i możliwość zastosowania ich w polskich warunkach, Sulejów 26-28 kwietnia 2017 r.}

W jednym z najlepiej zachowanych zespołów cysterskich w Europie, uznanym rozporządzeniem Prezydenta RP za pomnik historii, w Dolinie Rzeki Pilicy w Sulejowie, znajduje się Hotel Podklasztorze. XII-wieczne budowle Opactwa Cystersów przez stulecia przyjmowały w swoje progi wielu dostojnych gości: królów, książąt, artystów. Tym razem mury opactwa gościły uczestników XV Seminarium Badaczy Prawa Konstytucyjnego.

Myślą przewodnią kwietniowego spotkania było rozważanie tego, czy instytucje i rozwiązania prawne, które funkcjonują w państwach współczesnych, mogłyby zostać zastosowane w polskich warunkach. Uroczystego otwarcia obrad dokonał prof. dr hab. Krzysztof Skotnicki (Uniwersytet Łódzki), który serdecznie powitał uczestników, nawiązując przy tej okazji do spotkania, które miało miejsce równo 30 lat temu w tym samym miejscu. Wówczas na XXIX Ogólnopolskiej Sesji Katedr Prawa Konstytucyjnego w 1987 r. dyskutowano nad przyszłą polską konstytucją.

W pierwszej sesji, której przewodniczył prof. dr hab. K. Skotnicki, zostały wygłoszone cztery referaty. Jako pierwszy zabrał głos dr hab. Radosław Grabowski (Uniwersytet Rzeszowski), którego wystąpienie poświęcone było rozwiązaniom ustrojowym państw obcych w związku z usprawnieniem organizacji i funkcjonowania władzy ustawodawczej, wykonawczej i sądowni- 
czej w Polsce. Referent zwrócił chociażby uwagę na problematykę zastępstwa prezydenta na przykładzie instytucji wiceprezydenta w Republice Bułgarii.

Kolejny referat, który wygłosił dr Krzysztof Urbaniak (Uniwersytet im. Adama Mickiewicza w Poznaniu) poświęcony został problematyce kultury politycznej, kultury prawnej oraz normom niepisanym konstytucji jako elementom ustroju politycznego na przykładzie Wielkiej Brytanii. Autor odnosząc się do praktyki brytyjskiego systemu rządów, opartego na zwyczaju i konwenansie konstytucyjnym zwrócił uwagę na kilka bardzo istotnych kwestii: instytucjonalizację roli opozycji, upodmiotowienie opozycji oraz silną pozycję sądów. Dr K. Urbaniak podał szereg przykładów praktyki stosowania reguł nieprawnych konstytucji.

Kolejną osobą, której udzielono głosu był dr hab. Sławomir Patyra (Uniwersytet Marii Curie-Skłodowskiej w Lublinie). Wygłosił on referat pt.: „O racjonalizacji systemów rządów parlamentarnych III RP, czyli dwa do przodu, trzy do tyłu”. Dr hab. S. Patyra zaznaczył, iż jego zdaniem parlamentaryzm można racjonalizować nie tylko poprzez jurydyzację samą w sobie, ale także poprzez mechanizmy, które są otoczeniem prawa - np. poprzez elementy związane z praktyką ustrojową czy parlamentarną. W wystąpieniu autor skupił się na kwestiach normatywnych w odniesieniu do dwóch rozwiązań modelowych, które w zasadzie od 1989 r. stanowią zasadnicze punkty odniesienia dla kierunku zmian w polskim ustroju, tzn. modelu kanclerskiego i modelu półprezydenckiego, modelu w wersji V Republiki Francuskiej. Referent odniósł się, głównie krytycznie do dotychczasowych polskich wątków racjonalizacji parlamentaryzmu. Zasadnicze płaszczyzny, które zdaniem dr. hab. S. Patyry można jednocześnie potraktować jako wnioski de lege ferenda w odniesieniu do polskich rozwiązań, to przede wszystkim stabilność egzystencji rządu, efektywność realizacji programu politycznego przez rząd głównie kwestia oddziaływania rządu na proces ustawodawczy oraz jakość tworzonego prawa. Istotne są również same relacje w strukturze władzy wykonawczej, stosunek pomiędzy głową państwa a rządem, który podlega racjonalizacji bądź dysfunkcji.

Kolejny referat wygłosił dr hab. Piotr Uziębło (Uniwersytet Gdański). Wystąpienie dotyczyło możliwości recypowania rozwiązań ustrojowych Urugwaju w prawie polskim. Autor odniósł się do kilku regulacji w obrębie prawa wyborczego, omówił urugwajskie rozwiązania w zakresie funkcjonowania egzeku- 
tywy i sądownictwa. Dr hab. P. Uziębło dwa zagadnienia uznał za szczególnie interesujące i warte przemyślenia. Pierwsze z nich dotyczyło sposobu wyłaniania kandydata na prezydenta poprzez propozycję wprowadzenia instytucji prawyborów powszechnych. Drugi wiązał się z władzą sądowniczą. Urugwaj zastosował w tym zakresie dość specyficzne rozwiązanie oddzielając sądownictwo od pozostałych władz zarówno organizacyjnie, jak i ekonomicznie.

W trakcie dyskusji poruszano kwestię zasadności istnienia w obecnej formie instytucji prezydenta. Zastanawiano się również nad możliwością wprowadzenia do polskiego ustroju instytucji wiceprezydenta.

Drugi dzień obrad otworzyła sesja, której przewodniczyła dr hab. Sabina Grabowska (Uniwersytet Rzeszowski). Przedstawiono wówczas pięć referatów, z których pierwszy, autorstwa dr. Ryszarda Balickiego (Uniwersytet Wrocławski) dotyczył kanclerskiego modelu rządów. Referent zaproponował kilka rozwiązań, które widziałby w naszym modelu ustrojowym, a które dotyczą zakresu relacji między prezydentem a rządem (premierem). Punktem wyjścia miałaby być zmiana sposobu wybierania prezydenta, ale także, zdaniem autora, należałoby rozważyć kwestię weta prezydenta - zrezygnować czy raczej objąć kontrasygnatą. W dalszej części wystąpienia dr R. Balicki zastanawiał się również nad instytucją selektywnego wotum nieufności. Wskazał, że w sytuacji gdy rząd cieszy się poparciem wystarczająco liczebnej grupy posłów w Sejmie, wniosek o selektywne wotum nieufności jest nie tyle zbędny co bezsensowny. Natomiast w sytuacji rządu mniejszościowego powoduje tylko dezorganizację funkcjonowania rządu a w konsekwencji i państwa.

Tematem kolejnego referatu przygotowanego przez dr. Artura Olechno (Uniwersytet w Białymstoku) była „Semantyka konstytucyjnych norm kompetencyjnych na przykładzie krajów Europy Wschodniej”. Autor oparł swoje rozważania przede wszystkim na normach odnoszących się do instytucji prezydenta. Dr A. Olechno zauważył, że dwa najpopularniejsze rozwiązania na przyznawanie kompetencji czy przekazanie uprawnień, to kompetencja wskazana czasownikiem w liczbie pojedynczej rzadziej w liczbie mnogiej w czasie teraźniejszym, np. prezydent zarządza, prezydent zwołuje. Druga możliwość, to użycie partykuły może oraz bezokolicznika. Autor stwierdził, że partykuła może pozwala na wahanie się organu, podjęcie takiej bądź innej decyzji. Trzecia forma, która w konstytucjach pojawia się dość rzadko, to forma akcentująca kategoryczność. Dr A. Olechno posłużył się w tym miejscu 
przykładem zwrotu z art. 115 Konstytucji RP mają obowiązek, który pojawia się także w konstytucjach innych państw. Autor skonstatował, że prawodawca powinien być bardziej precyzyjny i konsekwentny w formułowaniu poszczególnych norm prawnych czy konstruowaniu przepisów.

Dr Małgorzata Lorencka (Uniwersytet Śląski) przedstawiła instytucję prawyborów we Włoszech. Odbywają się one na różnych szczeblach. Ich rola i znaczenie jest ogromna, szczególnie w kontekście aktywizacji grup wyborczych. Autorka omówiła prawybory otwarte, w których może brać udział każdy zarejestrowany wyborca i zamknięte, w których uczestniczą wyłącznie osoby zarejestrowane jako wyborcy danej partii, prawybory partyjne (jednej partii), prawybory koalicyjne, prawybory publiczne i prawybory prywatne.

Następny referat zatytułowany „Wybrane rozwiązania w zakresie organizacji wyborów w państwach hiszpańskojęzycznych - inspiracja dla ustawodawcy polskiego" wygłosiła dr hab. Anna Rakowska-Trela (Uniwersytet Łódzki). Autorka skupiła się przede wszystkim na kwestiach związanych z organami wyborczymi, ich konstrukcją i umocowaniem w krajowym porządku prawnym. Rozważając to zagadnienie, dr hab. A. Rakowska-Trela, wskazała jak ważne kompetencje spoczywają na organach wyborczych i jak istotne są one dla prawidłowego funkcjonowania państwa. Prawo wyborcze w Hiszpanii, odnośnie konstrukcji organów wyborczych, przyjęło dość ciekawe rozwiązanie. Organ ten stanowią sędziowie Sądu Najwyższego wyznaczeni w drodze losowania przez Radę Generalną Sądownictwa oraz profesorowie prawa, politologii lub nauk społecznych, powoływani na wspólny wniosek zgłaszany przez partie polityczne. Wyjątkowym rozwiązaniem jest wyznaczanie członków komisji szczebla podstawowego poprzez losowanie ich spośród wyborców. Autorka podjęła jeszcze kilka istotnych problemów, m.in. regulacje dotyczące publicznego liczenia głosów czy prowadzenia kampanii wyborczej. Następnie prelegentka poruszyła zagadnienia odnoszące się do rozwiązań funkcjonujących w Wenezueli i Nikaragui.

Drugą sesję zakończyło wystąpienie dr. Andrzeja Jackiewicza (Uniwersytet w Białymstoku) na temat „Referendum w sprawie rozwiązania Sejmu na Łotwie". Autor w toku referatu omówił uprawnienie przysługujące prezydentowi na podstawie art. 48 Konstytucji Łotwy do złożenia wniosku o rozwiązanie Sejmu. Przedstawił także kompetencję równoważącą uprawnienie prezydenta, jaką jest możliwość odwołania głowy państwa przez Sejm. W trakcie rozwa- 
żań nad tytułowym zagadnieniem, dr A. Jackiewicz, podjął próbę udzielenia odpowiedzi na pytanie, czy możliwe byłoby, w aktualnym stanie konstytucyjnym w Polsce, referendum w sprawie rozwiązania Sejmu RP.

Sesję podobnie jak poprzednią zakończyła ożywiona dyskusja nad poszczególnymi referatami. W przerwie obiadowej odbyło się także zebranie redakcji Przeglądu Prawa Konstytucyjnego.

III sesję, a drugą tego dnia, poprowadził dr hab. Krzysztof Eckhardt (WSPiA Rzeszowska Szkoła Wyższa). Jako pierwszy wystąpił dr hab. Jacek Zaleśny (Uniwersytet Warszawski) z referatem pt.: „Czynnik społeczny w orzekaniu, czyli o tym, czy obywatele powinni wybierać sędziów?” Inspiracją do tego wystąpienia był, jak przyznał prelegent, toczący się obecnie w Polsce proces prawno-polityczny w kontekście m.in. legitymizacji, demokratyzacji władzy sądzenia. Próby odpowiedzenia na pytanie na ile władza sądzenia jest władzą demokratyczną a na ile władzą, niejako wymykającą się spod rozwiązań demokratycznych, właściwych dla państwa prawnego. Jak zauważył autor, coś co przez wiele lat nie było przedmiotem pogłębionych a tym bardziej powszechnych rozważań politycznych czy prawnych przedostaje się dziś do dyskursu parlamentarnego i publicznego. W toku wystąpienia dr hab. J. Zaleśny analizował na ile władza sądzenia może być władzą motywowaną czynnikiem demokratycznym. Posłużył się doświadczeniami amerykańskimi - jak w systemie amerykańskim funkcjonują sędziowie pochodzący z wyborów, jakiego rodzaju modele tego wyboru są realizowane i jaka jest praktyka i ocena tego typu rozwiązań.

Kolejny referat w tej części seminarium przedstawił dr Piotr Czarny (Uniwersytet Jagielloński). W swoim wystąpieniu pt.: „Gwarancje niezależności sądownictwa konstytucyjnego w Niemczech i możliwości ich recepcji w Polsce" autor wnikliwie przeanalizował pozycję ustrojową Federalnego Trybunału Konstytucyjnego. Odniósł się do autonomii wewnętrznej i zewnętrznej Trybunału, jego miejsca w systemie organów państwa, mechanizmu kreacji oraz katalogu kompetencji.

Temat kolejnego referatu, przygotowanego przez dr hab. Marcina M. Wiszowatego (Uniwersytet Gdański), brzmiał „Gdy honor przegrywa z polityką - czyli przeproś albo giń. O etyce parlamentarnej II i III RP i zagranicą”. Jak zauważył referent połączenie w jednym miejscu honoru i polityki, bądź etyki i polityki jest dla większości obserwatorów naszej rzeczywistości poli- 
tycznej kiepskim pomysłem. Przedmiotem wystąpienia dr hab. M.M. Wiszowaty uczynił jedynie część działalności deputowanych, skupiając się na relacjach posłów z innymi posłami, ze względu na fakt iż jest to najczęstszy przedmiot naruszeń etyki poselskiej. Prelegent przedstawił charakterystykę komisji etyki poselskiej, wypracowane przez nią zasady etyki poselskiej oraz grożące za ich naruszenie sankcje. Autor poddał również analizie rozwiązania innych państw. Zdaniem dr. hab. M.M. Wiszowatego należałoby postulować przywrócenie sądu honorowego ad hoc, wprowadzenie sankcji w postaci przeprosin na wzór brytyjski, także pozbawienie funkcji w Sejmie oraz szkolenia dotyczące etyki poselskiej.

Ostatni w tej sesji referat przedstawił dr hab. Konrad Składowski (Uniwersytet Łódzki). Tematem jego wystąpienia był „Zastępca posła w chorwackim prawie parlamentarnym”. Autor omówił pokrótce sytuację na scenie politycznej Chorwacji, rolę partii politycznych, która wiąże się bezpośrednio z praktyką stosowania instytucji zastępcy posła. Przedstawił jakie były powody wprowadzenia omawianej instytucji i jak przedstawia się ona z praktycznego punktu widzenia. Na koniec prelegent zastanawiał się nad możliwością wprowadzenia instytucji zastępcy posła w polskich realiach, wywołując tym samym kolejną ożywioną dyskusję.

Po zakończeniu dyskusji dr hab. K. Składowski dokonał uroczystego zamknięcia seminarium. Podziękował uczestnikom za udział w spotkaniu i dyskusję, a referentom za ich wkład merytoryczny. Następnie poinformował o kolejnym seminarium, którego organizatorami będą przedstawiciele Uniwersytetu w Białymstoku.

Kamila M. Bezubik Uniwersytet w Białymstoku 